\title{
Notes on Contributors
}

Mateusz Antoniuk works at Jagiellonian University (Faculty of Polish Studies) in Cracow, Poland. In 2014 he was a postdoctoral fellow at the Beinecke Library, Yale University; and he was also a guest lecturer at the University of Bologna and at Immanuel Kant Baltic Federal University. Antoniuk's special research field is genetic criticism's theory and practice. $\mathrm{He}$ is the author or co-author of four monographs, including Pracownia Herberta (2017) and Slowo raz obudzone Poezja Czeslawa Milosza proby czytania (2015), as well as many articles devoted to the history of Polish literature. He is a member of the American Society for Textual Scholarship and the European Society for Textual Scholarship. In June 2019, Antoniuk served as the main organizer for the international conference "GenesisCracow 2019" held by Jagiellonian University and ITEM, Paris.

Edward Bowen is Assistant Teaching Professor of Italian at the University of Kansas. He specializes in Italian film history, film exhibition, independent cinema, and contemporary Italian culture. He recently coedited The Cinema of Ettore Scola (Wayne State University Press, 2020) with Rémi Lanzoni, and he published a chapter on trade stories and media paratexts in Experimental and Independent Italian Cinema (Edinburgh University Press, 2020), edited by Anthony Cristiano and Carlo Coen. He has also published articles on film exhibition history in Rome in Cinema e storia and in the Journal of Italian Cinema and Media Studies. Bowen studied Italian literature and film at the University of Wisconsin (MA 2008) and Indiana University ( $\mathrm{PhD} 2015)$.

Amber Brian is Associate Professor of Latin American Literary and Cultural Studies in the Department of Spanish and Portuguese and Director of the Latin American Studies Program at the University of Iowa. Her primary areas of research include Colonialism and Historiography, Indigenous Intellectual History, and Translation Studies. Her first book, Alva Ixtlilxochitl's Native Archive and the Circulation of Knowledge in Colonial Mexico (2016), was awarded honorable mention for the Modern Language 
Association's Katherine Singer Kovacs Prize. In collaboration with Bradley Benton, Peter B. Villella, and Pablo García Loaeza, and with the support of the NEH, she edited and translated History of the Chichimeca Nation: Don Fernando de Alva Ixtlilxochitl's Seventeenth-Century Chronicle of Ancient Mexico (2019), and, with Benton and García Loaeza, The Native Conquistador: Alva Ixtlilxochitl's Account of the Conquest of New Spain (2015). Her current book project looks at questions of imperial authority, Native sovereignty, and trans-oceanic communication in epistolary correspondence between king and Indigenous vassals in sixteenth-century New Spain.

Valerio Cellai recently completed a short-term research fellowship focused on framing a project on Lucca's medieval manuscripts that may be attributed to Dante's times. He is currently a $\mathrm{PhD}$ candidate at the University of Pisa, where his main research interests lie in manuscript studies, digital humanities, and Italian literature of the fourteenth and fifteenth centuries, with a special interest in the Italian novella (Giovanni Boccaccio's Decameron, the Motti e Facezie del piovano Arlotto with their respective philosophical and literary backgrounds).

Gloria E. Chacón is Associate Professor in the Literature Department at the University of California San Diego. She is the author of Indigenous Cosmolectics: Kab'awil and the Making of Maya and Zapotec Literatures (2018). She is co-editor of Indigenous Interfaces: Spaces, Technology, and Social Networks in Mexico and Central America by Arizona Press (2019). She has co-edited a special issue on indigenous literature for DePaul's University academic journal, Diálogo. Chacón's work has appeared in anthologies and journals in Canada, Colombia, Germany, Mexico, and the USA. She is currently working on her second book tentatively titled Metamestizaje, Indigeneity, and Diasporas: New Cartographies of Being and has a forthcoming co-edited anthology, Teaching Central American Literature in a Global Context for MLA's Teaching Options Series.

Francesco Feriozzi earned a Bachelor's Degree in Lettere Moderne, a Master's Degree in Filologia Moderna, Università degli Studi di Roma "Sapienza", and is currently a DPhil student at the University of Oxford. His dissertation is on the influence of the rediscovery of Occitan on the Cinquecento Questione della lingua and will also include a critical edition of Giammaria Barbieri's Arte del Rimare. Among his other research interests are theory and methods of philology (traditional and authorial alike), troubadour poetry, and the works of Alessandro Manzoni. 
Suzanne Gossett is Professor Emerita of English at Loyola University Chicago. She writes frequently on textual matters and is a General Textual Editor of the Norton Shakespeare, third edition, and General Editor of Arden Early Modern Drama. Her recent editions include All's Well That Ends Well and Pericles (Arden 3), Eastward Ho! (Cambridge Works of Ben Jonson), and plays by Middleton and Beaumont and Fletcher. Currently she is editing Sophonisba or The Wonder of Women for the Oxford works of John Marston. She is a past president of the Shakespeare Association of America.

Tiziana Mancinell obtained a PhD in Italian Literature and Digital Humanities from the University of Reading, United Kingdom, where she completed a scholarly digital edition of Attilio Bertolucci's La camera da letto. After taking her first degree at University of Rome "La Sapienza" in Contemporary Literary Studies, she collaborated with the CRILet (Centro Ricerche Informatica e Letteratura), under the supervision of Giuseppe Gigliozzi, as well as with the Cologne Center for eHumanities. She currently holds a Post-doc at Ca' Foscari University of Venice, where she specializes on ontologies and Linked Data. She co-authored Che cos'è un'edizione scientifica digitale with Elena Pierazzo (Rome: Carocci, 2020).

Antonio Montefusco, educated at the University of Rome "La Sapienza", has collaborated with several French and German institutions, and in 2014 earned an ERC Start-up Grant for a research project on the social history of medieval translation. A specialist in the Franciscan movement between the thirteenth and fifteenth centuries, his research focuses on the history of the culture of this religious order and, in particular, its dissident currents (Iacopone da Todi, Ubertino da Casale, Angelo Clareno, i fraticelli). He studies institutions, documents, culture, and memory in the communal Middle Ages, in particular in relation to the Latin and vernacular literature of the period (Guittone, Brunetto, Dante, Francesco da Barberino).

Beatrice Nava is a PhD candidate in Literary and Philological Cultures at the University of Bologna, with primary interests in Modern Philology and Digital Editing. She is working on a critical and digital edition of Manzoni's tragedy Il Conte di Carmagnola. She is also collaborating on a PRIN project, ManzoniOnline, and she is involved in the Digital Humanities Advanced Research Centre (University of Bologna). She has taught $\mathrm{XML} / \mathrm{TEI}$ coding of literary text in seminars at the University of Bologna, 
where she also is Teaching Tutor in the Department of Modern Languages, Literatures, and Cultures.

Marcos Antonio Norris is a Crown Fellow of English at Loyola University Chicago, where he is completing a dissertation on Hemingway, Sartre, and the Secularization of Religious Belief. Marcos is co-editor of the soon-to-be-published collection of essays Agamben and the Existentialists (Edinburgh University Press) and the author of numerous peer-reviewed articles, most recently including "Gender Pronoun Use in the University Classroom: A Posthumanist Perspective" in Transformation in Higher Education and "Her voice is full of money': Mechanical Reproduction and a Metaphysics of Substance in F. Scott Fitzgerald's The Great Gatsby" in English Studies. His research focuses on the intersections between contemporary continental thought, existentialism, and twentieth-century literature.

Lauren Alex O'Hagan is a research associate in the Centre for Language and Communication Research at Cardiff University. Her current project is entitled "Reading, Writing and. . . Rebellion: Understanding Literacies and Class Conflict Through the Edwardian Book Inscription" and is funded by the Economic and Social Research Council. Her research interests and publications focus largely on class conflict, literacy practices, and consumer culture in Victorian and Edwardian Britain using a multimodal ethnohistorical lens.

Beatrice Pecchiari is a PhD student in Italian Studies at the University of Pisa. She completed her B.A. and M.A. at Sapienza University of Rome where she graduated with a thesis on the critical and genetic study of Una lapide in via Mazzini by Giorgio Bassani (Premio "Robert Nissim Haggiag" [2019]). She has co-edited the collection of interviews of Giorgio Bassani, Interviste 1955-1993 (Milano: Feltrinelli, 2019). Her research interests include Italian literature and philology of the nineteenth and twentieth centuries and correspondences.

Veijo Pulk kinen earned his PhD in literature at the University of Oulu in 2010; and in 2018, he was awarded the Title of Docent at the University of Helsinki. From 2011 to 2014 Pulkkinen worked as a postdoctoral researcher funded by the Academy of Finland. He has published a monograph, Runoilija latomossa: geneettinen tutkimus Aaro Hellaakosken Jääpeilistä (2017) [The poet in the typesetting room: a genetic study on Aaro Hellaakoski's Jääpeili], and articles on visual poetry and the application of 
genetic and textual criticism to literary interpretation. In his current project, Pulkkinen studies the role of the typewriter in Finnish literature from genetic and medial perspectives.

Andrew Reynolds is a Professor of Spanish at West Texas A\&M University. He is interested in how textuality and visual representation affects cultural production in Latin America from 1870 to 1930 . Recently with Heather Allen he published the edited collection Latin American Textualities: History, Materiality $\mathcal{F}$ Digital Media (2018). In 2018 he was a guest editor of a special issue on Rubén Darío and Modernismo for Review: Literature and Arts of the Americas. He is finishing his current monograph project titled Reflecting the Fin de Siglo: Print and Visual Media in Spanish America at the Turn of the 20th Century.

Stefan Schöberlein is an Assistant Professor of English and the Digital Humanities at Marshall University. His research focuses on the intersections of science, literature, and technology in the nineteenth century. He has published extensively on the poet Walt Whitman, including a translation of Whitman's novel Jack Engle into German. He serves as vicepresident of the Digital Americanists Society, and is a contributing editor to the Walt Whitman Archive as well as co-editor of Movable: Narratives of Recovery and Place.

Jorge Téllez is Assistant Professor of Romance Languages at the University of Pennsylvania. His work focuses on colonialism in Latin America, past and present. His book The Picaresque and The Writing Life in Mexico is forthcoming with Notre Dame University Press in Spring 2021.

Serena Vandi is Powys Roberts Research Fellow at St Hugh's College, University of Oxford, where she works on the project "Gadda: Fascism, Satire and Truth". She was awarded her PhD in Italian at the University of Leeds, with the thesis "Satura: Truth through Variety in Dante and Gadda". She obtained her B.A. and M.A. at the University of Bologna, where she was a student at the Collegio Superiore. Alongside her research, she teaches Dante Alighieri and nineteenth- and twentieth-century Italian literature.

Michelangelo Zaccarello is professor of Italian Philology at the University of Pisa, following previous teaching posts in Dublin, Oxford, and Verona. His research interests revolve around the textual scholar- 
ship of early Italian literature, especially in Renaissance authors, chiefly Burchiello and Luigi Pulci, whose sonnets he published in critical editions (respectively, Bologna: Commissione per i Testi di Lingua, 2000 and Florence: Franco Cesati, 2017). His research interests were recently extended to Early Italian prose texts (Boccaccio, Paolo da Certaldo, Sacchetti) and related linguistic problems. He joined the Society for Textual Scholarship in 2011; on textual theory and editing methodology, he recently published the volumes L'edizione critica del testo letterario (Milan: Mondadori 2017) and Teoria e forme del testo digitale (Rome: Carocci 2019). 